\title{
Accessing camera trap survey feasibility for estimating Blastocerus dichotomus (Cetartiodactyla, Cervidae) demographic parameters
}

\author{
Pedro Henrique F. Peres, Maxihilian S. Polverini, Márcio L. Oliveira \& José Maurício B. Duarte
}

Núcleo de Pesquisa e Conservação de Cervídeos (NUPECCE), Universidade Estadual Paulista (Unesp), Faculdade de Ciências Agrárias e Veterinárias (FCAV) Via de Acesso Paulo Donato Castellane, s/n, 14884-900, Jaboticabal, São Paulo, Brazil. (pedrof182@gmail.com)

\begin{abstract}
Demographic information is the basis for evaluating and planning conservation strategies for an endangered species. However, in numerous situations there are methodological or financial limitations to obtain such information for some species. The marsh deer, an endangered Neotropical cervid, is a challenging species to obtain biological information. To help achieve such aims, the study evaluated the applicability of camera traps to obtain demographic information on the marsh deer compared to the traditional aerial census method. Fourteen camera traps were installed for three months on the Capão da Cruz floodplain, in state of São Paulo, and ten helicopter flyovers were made along a 13-kilometer trajectory to detect resident marsh deer. In addition to counting deer, the study aimed to identify the sex, age group and individual identification of the antlered males recorded. Population estimates were performed using the capture-mark-recapture method with the camera trap data and by the distance sampling method for aerial observation data. The costs and field efforts expended for both methodologies were calculated and compared. Twenty independent photographic records and 42 sightings were obtained and generated estimates of 0.98 and $1.06 \mathrm{ind} / \mathrm{km}^{2}$, respectively. In contrast to the aerial census, camera traps allowed us to individually identify branch-antlered males, determine the sex ratio and detect fawns in the population. The cost of camera traps was $78 \%$ lower but required 20 times more field effort. Our analysis indicates that camera traps present a superior cost-benefit ratio compared to aerial surveys, since they are more informative, cheaper and offer simpler logistics. Their application extends the possibilities of studying a greater number of populations in a long-term monitoring.
\end{abstract}

KEYWORDS. Aerial survey, capture-recapture, distance sampling, population estimate, sex ratio.

RESUMO. Avaliação da viabilidade do uso de armadilhas fotográficas para estimar parâmetros demográficos de Blastocerus dichotomus (Cetartiodactyla, Cervidae). Informações demográficas constituem a base para a avaliação e planejamento de estratégias de conservação de uma espécie ameaçada. No entanto, em muitas situações existem limitações metodológicas ou financeiras para a obtenção de tais informações para algumas espécies. O cervo-do-pantanal, um cervídeo neotropical ameaçado de extinção, é uma espécie desafiadora para obtenção de informações biológicas. Para suprir essa demanda, o presente trabalho avaliou a aplicabilidade das armadilhas fotográficas para obtenção de informações demográficas de cervo-do-pantanal em comparação com o tradicional método de censo aéreo. Na várzea Capão da Cruz, Estado de São Paulo, foram instaladas 14 armadilhas fotográficas durante três meses e realizados dez sobrevoos de helicóptero num trajeto de $13 \mathrm{~km}$ para detecção dos cervos-do-pantanal ali residentes. Além da contagem dos animais, objetivou-se identificar o sexo, a faixa etária e a identificação individual dos machos galhados registrados. As estimativas populacionais foram realizadas pelo método de captura-marcação-recaptura com os dados de armadilhas fotográficas e pelo método de amostragem por distâncias para os dados de observação aérea. Foram contabilizados e ponderados os custos e esforços de campo despendidos para ambas metodologias. Obteve-se 20 registros fotográficos independentes e 42 visualizações que geraram estimativas de 0,98 e 1,06 ind. $/ \mathrm{km}^{2}$ respectivamente. Ao contrário do censo aéreo, as armadilhas fotográficas permitiram a identificação individual dos machos galhados, a proporção sexual e a detecção de filhotes na população. O custo das armadilhas fotográficas foi $78 \%$ menor, porém demandou um esforço de campo 20 vezes maior. Avaliamos que as armadilhas fotográficas apresentaram uma relação custo-benefício superiores em relação aos levantamentos aéreos, por ser mais informativa e barata e com uma logística mais simples. Sua aplicação abre a possibilidade para o estudo de um número maior de populações e o monitoramento contínuo e de longo prazo.

PALAVRAS-CHAVE. Contagem aérea, captura-recaptura, amostragem por distância, estimativa populacional, razão sexual.

Demographic parameters play a central role in wildlife conservation management. Thus, population surveys are auxiliary tools in defining the purposes of management of wild populations and allow for adequate management of small or declining populations.

The marsh deer Blastocerus dichotomus Illiger, 1815 (Cervidae) is the largest deer in the Neotropical region, with individuals weighing up to $150 \mathrm{~kg}$ (PINDER \& Grosse, 1991). Adult males possess robust antlers with a dichotomous pattern that normally have 10 points (HoFMANN et al., 1976; DuARTE, 1996) and are about $60 \mathrm{~cm}$ in length (CABRERA, 1961). The cycle of antler shedding is apparently individual, and individuals with antlers are found in nature at any time of year (H. G. C. Ramos, unpubl. data). An inhabitant of wetlands and marshes, the marsh deer has interdigital membranes, markedly elongated hooves and relatively long limbs, denoting adaptation of the species to these environments. Historically, this species occurred over a large area, in the center of the Neotropical region covering most of the lowlands located east of the Andes, 
from the headwaters of the southern Amazon basin to the Paraná River delta. Currently, the distribution of the marsh deer is greatly reduced and fragmented, consisting mostly of relictual populations (DUARTE et al., 2016). The highest concentrations of this species can be observed in the Brazilian Pantanal, in the region of Bananal Island, the Araguaia River, the Guaporé River and the floodplain remnants of the Paraná River, and three regions in Argentina (DUARTE et al., 2012).

In the last century, an intense decline in population occurred and led to the disappearance of several populations. This reduction was due to four main factors: the advancement of agricultural and urban frontiers, diseases introduced by domestic cattle, predatory hunting activities and, more recently, the construction of large hydroelectric power plants (Pinder, 1996; DuARTE et al., 2012; ANDriolo et al., 2013). In view of this situation, the International Union for Conservation of Nature (IUCN) Red List now lists the status of the marsh deer as Vulnerable (VU A4cde) (DUARTE et al., 2016).

Among the methods for estimating deer populations, aerial surveys have been used worldwide (CAUGHLEY, 1977; KoERTH et al., 1997; ANDRIOLO et al., 2005), and applied for the marsh deer since 1976 (SCHALLER \& VASCONCELOS, 1978). Studies involving aerial surveys estimated a density of $0.54 \mathrm{ind} / \mathrm{km}^{2}$ in the Paraná River basin (PINDER, 1996), $0.32 \mathrm{ind} / \mathrm{km}^{2}$ in the Brazilian Pantanal (MourÃo et al., 2000), $0.57 \mathrm{ind} / \mathrm{km}^{2}$ in Rio Negro State Park (Tomas et al., 1997) and $0.35 \mathrm{ind} / \mathrm{km}^{2}$ in Porto Primavera (ANDRIOLO et al., 2005). The use of airplanes and helicopters, together with the linear transect technique, offers certain advantages, since the species occurs in areas of open floodplain that facilitate sightings (ANDRIOLO et al., 2005), while being difficult to access by land. However, this method may be infeasible for brief surveys of small populations, given the high cost of aircraft flights and the need for long journeys to access remote areas.

In comparison, camera traps have been one of the most efficient and dynamic tools for evaluating and monitoring fauna (Ridout \& Linkie, 2009; Rovero \& MARSHALl, 2009). The use of this tool has proven to be efficient for studying species with relatively wide dispersion that occur at minimal densities, are solitary or live in very small groups (CARBOne et al., 2001). Moreover, camera traps combined with the use of capture recapture models have been the main method used to estimate populations of felines, since they have natural spots, stripes and rosettes that can individualize the animals based on different body markings (KARANTH \& Nichols, 1998; KARANTH et al., 2004).

The main limitation of using camera traps for population estimates is the difficulty in identifying individual animals that usually do not have natural markings. However, some studies have shown that scars, subtle marks, differences in coat colors and body structure afford a reliable individual recognition from camera trap records, including cases such as tapirs (Noss et al., 2003; Trolle et al., 2008), maned wolves (Trolle et al., 2006) or cougars (Kelly et al., 2008) in South America. Although the use of capture-recapture method in these cases had its reliabitily criticized due to the ability of ambiguous identifications and small proportion of correct identifications in the sampled individuals could impact the results (FosTER \& HARMSEN, 2012). Regarding cervids, some Neotropical species possess branched antlers (Odocoileus, Blastocerus, Ozotoceros and Hippocamelus), thus distinct morphology can be used for individual identification. One example is the pioneering study by JACOBSON et al. (1997), who conducted population surveys of white-tailed deer [Odocoileus virginianus (Zimmermann, 1780)] using camera traps. This protocol has been used to estimate cervid populations from camera traps, together with the capturemark-recapture method (DEYounG, 2011).

The direct cost-benefit comparison of aerial and camera trap surveys to estimate density was only assessed once and brought a constructive perspective to encourage camera trap studies in deer populations in the United States (Koerth et al., 1997). Therefore, the purpose of this study was to assess the viability of camera traps for estimating population parameters (density, sex ratio, and age proportion) compared to the aerial survey method for the first time in the Neotropical context applied to the marsh deer.

\section{MATERIAL AND METHODS}

Study area and focal population. The study was conducted on the Capão da Cruz floodplain (21 34 '44.5'S $\left.47^{\circ} 52^{\prime} 00.1^{\prime \prime} \mathrm{W}\right)$, a wetland area of 1,512 ha along the banks of the Mogi-Guaçu River. This area is delimited to the south by the Moji-Guaçu River, to the north by a sugar cane plantation, to the west by a eucalyptus plantation, and to the east by a semideciduous seasonal forest that forms part of the Estação Ecológica do Jataí. The region is located in the Cerrado biome and within the municipality of Luís Antônio in the State of São Paulo, Brazil (Fig. 1).

The populations of marsh deer that inhabited the floodplains of the Mogi-Guaçu River were extinct in the early twentieth century (JUNQUEIRA, 1940). An ex situ and a reintroduction conservation program of the marsh deer were initiated once the construction of the "Engenheiro Sérgio Motta" Hydroelectric Plant, in the Paraná River, was finished and vanished most of the local population of the species. One of the targets of the reintroduction program was the Capão da Cruz floodplain, where eight marsh deer (3 males, 5 females) were reintroduced between 1998 and 2001. FigueIRA et al. (2005) studied the patterns of the space use of the reintroduced deer using radio-telemetry, and reported that the home ranges of the deer varied between 0.48 to $4.06 \mathrm{~km}^{2}$. In a subsequent work was estimated the home range of reintroduced deer and those born in the Estação Ecológica do Jataí, reporting mean home range of $1.17 \mathrm{~km}^{2}$ in the rainy season and $1.40 \mathrm{~km}^{2}$ in the dry season (M. A. A. Perin, unpubl. data).

The study area presents a climate corresponding to the Koppen classification "Aw", with marked wet and dry seasons. Summer presents high temperatures and rainfall from December to March and the winter is marked by low 


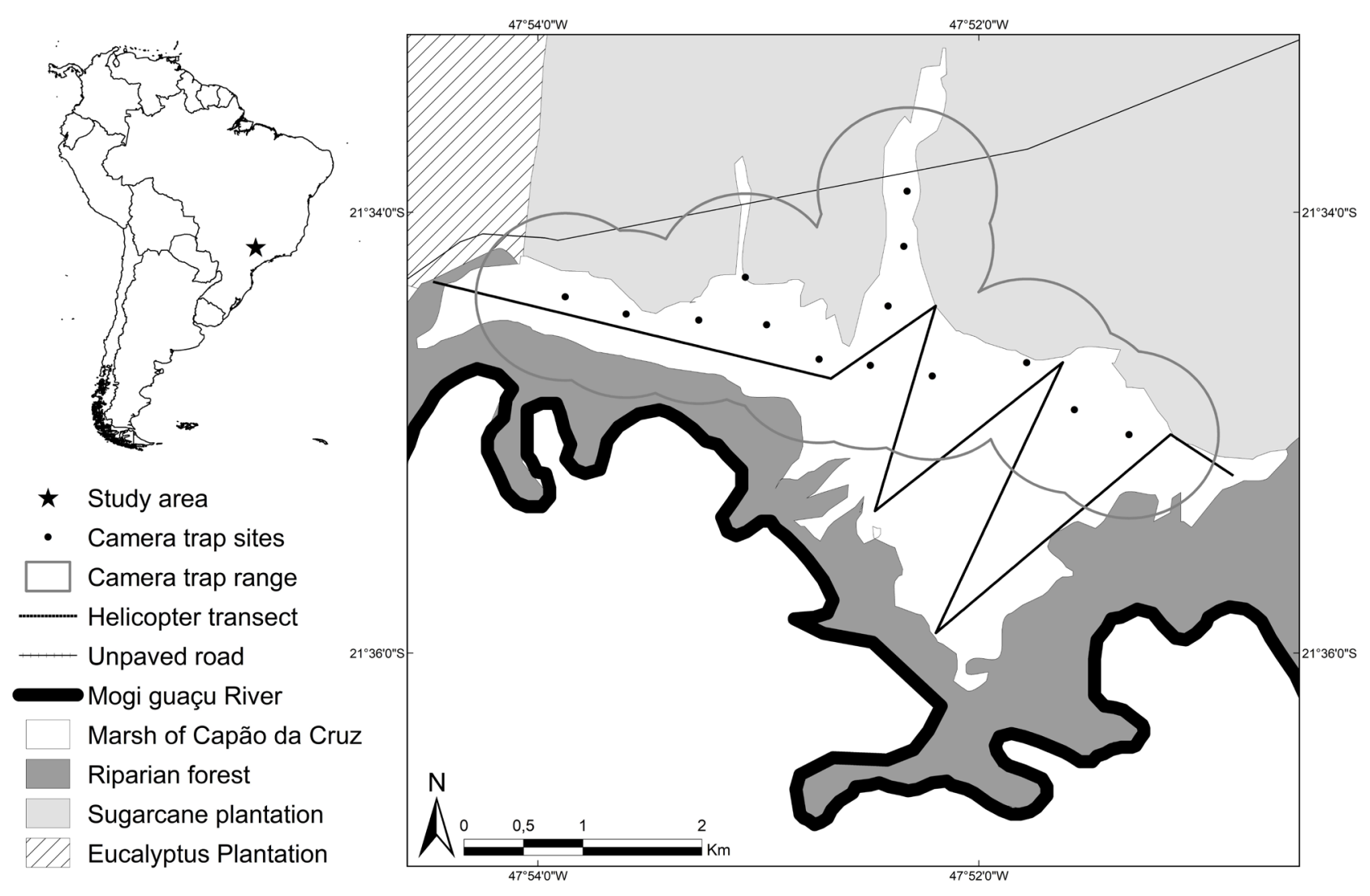

Fig. 1. Map outlining the aerial and camera trap surveys conducted at the Jataí Ecological Station, state of São Paulo, Brazil in order to obtain marsh deer demographic parameters.

temperatures and rainfall from May to August (SÃo PaUlo, 2013). Surveys were conducted in different years but both in the same season to mitigate seasonal effects on movement and density patterns. In both sampling periods (AugustNovember) the environment was dry and the water level of the floodplain and the Mogi Guaçú River was low because of the final phase of the dry season. In this context, marsh deer present larger home ranges and low density levels due to higher habitat availability but lower food availability (M. A. A. Perin, unpubl. data).

Camera trap survey. Fourteen Tigrinus Digital 6.3D traps were installed on artificial wooden supports in the marsh land. The traps operated $24 \mathrm{~h}$ per day for 68 days, from September to November, 2013. The total sampling effort comprised 952 camera trap days. However, some camera traps did not work full time due to malfunction. Thus the exact effort accounted was 13,104 hours. Locations that presented indirect traces of the marsh deer, such as trails, tracks, beds and feces, were chosen when installing the equipment. The camera traps were checked every two weeks to replace batteries and memory cards. We considered that each camera trap would have a high probability of detecting resident deer within a radius of at least $700 \mathrm{~m}$ from the point of installation. This measurement is based on the method denominated "half mean maximum distance moved" (WILSON \& ANDERSON, 1985; KARANTH et al., 2004) and the calculation took account the diameters of the home range of the marsh deer studied in the dry season on the Capão da Cruz floodplain (M. A. A. Perin, unpubl. data). Given the extreme difficulties in accessing regions with deeper waters, camera traps were not installed in these locations, but were restricted to the outer edges of the floodplain. This design does not affect sampling, as previous reports show that the species use the entire floodplain gradient, from the river to its edges (Figueira et al., 2005; M. A. A. Perin, unpubl. data), and avoid environments where water is more than $60 \mathrm{~cm}$ deep (SCHALlER \& VASCONCELOS, 1978).

Estimating the population parameters (density, sex ratio and age proportions) was based on the work of JACOBSON et al. (1997), who used capture-mark-recapture models to estimate the number of branch-antlered males and extrapolated this data to the rest of the population based on the proportions of the remaining groups in the records. For this purpose, the population was divided into four groups in accordance with JACOBSON et al. (1997)'s subdivisions: branch-antlered males, spike-antlered bucks, females and fawns. The branch-antlered males class refers to males with at least two tines on each side of the antler rack. Marsh deer antlers can reach more than 10 times in a bifurcated arrangement that represent a morphological diversity capable of being individualized (PEREIRA, 2010). Spiked antlers do not provide sufficient characteristics for individualization, 
so males with this configuration were considered a different group. This group is mainly composed of young bucks who typically had simple spiked antlers in their first antler cycle (H. G. C. Ramos, unpubl. data). The third group is composed of adult females and the fourth one by fawns, identified only in their first year when they still follow their mothers closely.

Branch-antlered males were identified individually after studying antler morphology and configuration (number of points, length and direction of branches). Based on this group, population estimation by capture-mark-recapture was performed using the SCHUMACHER \& ESCHMEYER (1943) method, implemented using the software Ecological Methodology 5.1 (KENNEY \& KREBS, 1998). Because of the short study period, the population was considered closed once deaths, births and migrations are unlikely. Photographs captured at intervals of less than $15 \mathrm{~min}$ between shots were discarded to ensure the independence of the recordings.

The cost of conducting the camera trap survey took into account the market price of the equipment used, adjusted according to its useful life and the period of use during the study. From personal experience and that of colleagues, we considered a useful life of three years. The cost of purchasing memory cards and batteries was added to this figure (which include the field transport and batteries costs basically). Determining the field efforts required to execute this methodology involved the time spent by two field technicians strictly to install and check the equipment on the Capão da Cruz floodplain.

Aerial survey. The aerial survey was conducted during ten flyovers, one per day, between August and September 2015. These flyovers began around 9 AM and used a Robinson R44 helicopter, with the rear doors removed, which flew a $13 \mathrm{~km}$ transect (Fig. 1) at a mean velocity of $26 \mathrm{~km} / \mathrm{h}$ and an altitude of $50 \mathrm{~m}$ above the ground. The technical team consisted of a pilot and a crewmember who recorded the sightings, both seated at the front of the aircraft, and two observers, one on each side seated at the rear. After sighting the deer, the observers defined their angulation in relation to the horizon by means of a manual clinometer. The angle was used to calculate the distance the deer was in relation to the transect flown by the helicopter. Whenever possible, the sex and age of individual deer were recorded. We do not estimate a specific age for individuals but only recorded whether it was a fawn, in the case of small sized deer following their mothers, or a juvenile male, in the case of spike-antlered males. Marsh deer fawns are known to follow their mothers for at least for 6 months during lactation and early development and hard spiked antlers are characteristic of the first antler cycles in juveniles (Piovezan et al., 2010; Pereira, 2010).

The distances of the individual deer sighted in relation to the transect flown were used as a database for distance sampling analysis in the Distance 6.2 software (ThOmas et al., 2010). To estimate the detectability, different models were tested-uniform, half-normal and hazard-rate key-, with cosine and Hermite polynomial adjustments. The best fit function was determined by the Akaike information criterion
(AIC) index (AKAIKE, 1985), as implemented by LAAKE $e t$ al. (1993).

The cost of conducting the aerial survey took into account the market price of the helicopter rental only during the flyovers of the transect. The cost of traveling from the heliport to the study area and back were excluded, as this can vary depending on the location of the study. The time required to execute this methodology involved the time spent by the three technicians strictly during the flight along the transect over the Capão da Cruz floodplain.

\section{RESULTS}

Sampling using camera traps recorded 62 occurrences of marsh deer, of which 20 were considered independent and valid for subsequent analyzes. Among these, 11 were antlered males, two were males with unbranched antlers, six were females and one was a fawn. The ratios between the groups were calculated based on these recordings: the proportion of branch-antlered males to spike-antlered males was 5.5:1; spike-antlered males to females was 1:3; and females to fawns was 6:1. Six males were identified individually, with five recaptures (Figs 2-5). These records determined a capturemark-recapture estimate of 7.8 (95\%CI, 5.5-13.4) branchantlered males in the study area. Applying the proportions calculated for each group of the population results in a total of 14.8 (10.5-25.5) individuals and a density of $0.98(0.69-1.66)$ ind $/ \mathrm{km}^{2}$ on the Capão da Cruz floodplain (Tab. I).

The total cost of the camera traps was US\$ 6,020 (US\$ 430 per unit), which adjusted for the useful life of the equipment and time used in the survey resulted in US\$ 495 (US\$ 35.36 per unit). The cost of maintenance and changing batteries was US\$155, so the total cost for camera trap sampling was US\$ 650 . The field effort was estimated at $150 \mathrm{~h}$ of work performed by two people.

The aerial survey resulted in 42 sightings of marsh deer. Deer only showed a reaction in response to the helicopter on three occasions. All the sightings were of adult deer, on most occasions it was not possible to identify the presence or absence of antlers, though nine sightings of antlered males were recorded. When performing analyses with Distance software, the function that best adapted to the data was Uniform with cosine adjustment, resulting in a density of $1.06(0.58-1.9) \mathrm{ind} / \mathrm{km}^{2}$ (Tab. I). This density applied to the area of the Capão da Cruz floodplain results in an estimate of $16(8,76-28,72)$ marsh deer.

The estimated cost for the aerial survey was US\$ 3000 (US\$ 600/h), with a field effort of $5 \mathrm{~h}$ performed by a team of three people.

\section{DISCUSSION}

The individual identification of antlered males has been applied to other deer species, including the mule deer (SHIELDS et al., 2012), sika deer (DougherTy \& Bowman, 2012) and white-tailed deer (JACOBSON et al., 1997), though to our knowledge, this is the first study to apply 

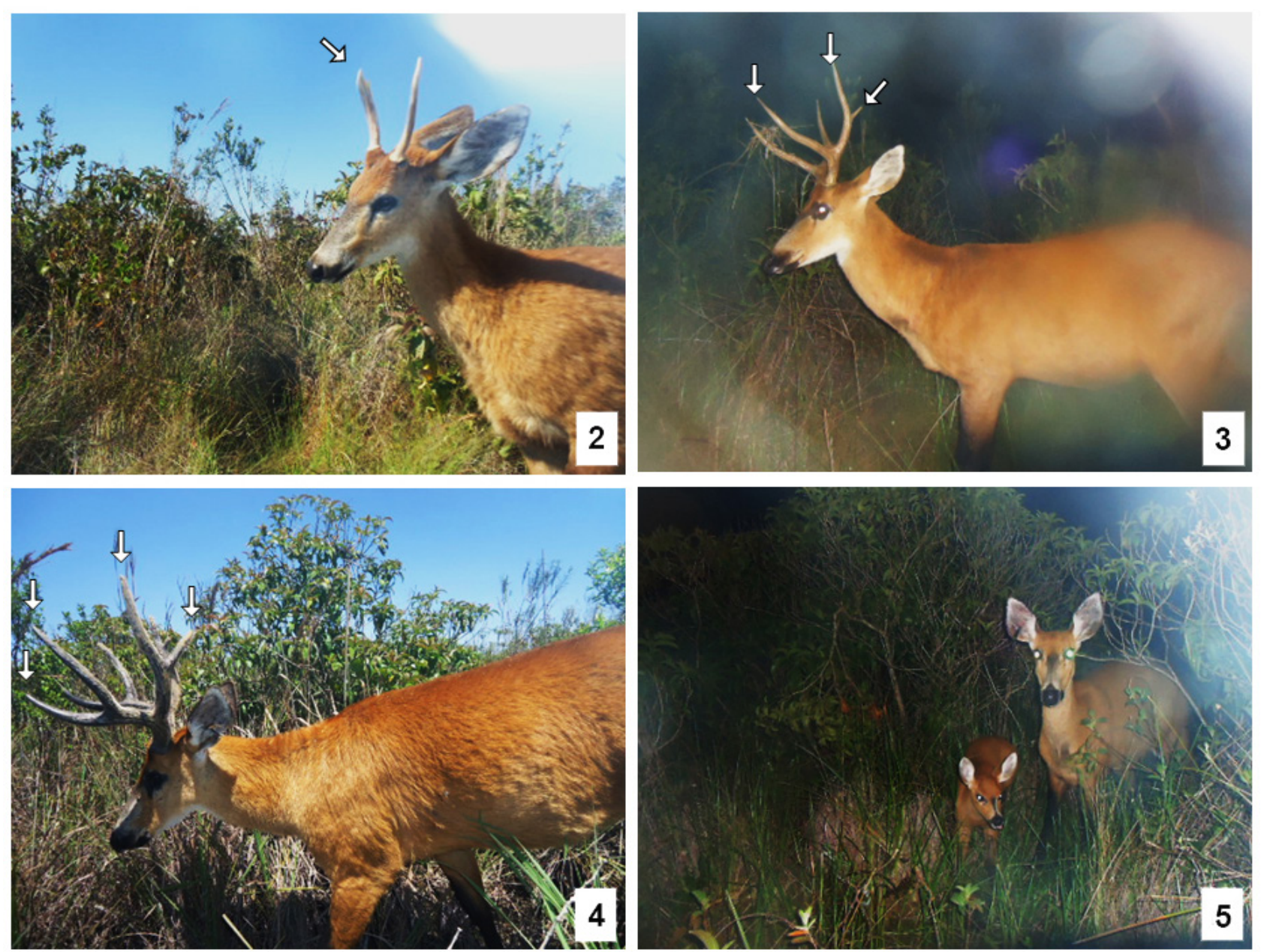

Figs 2-5. Individual discrimination of marsh deer males (Blastocerus dichotomus Illiger, 1815) using antler morphology: a spike-antlered male (2) and two different branched antlers ( 3 and 4 ). The arrows indicate the different horn tips. Marsh deer female accompanied by a fawn (5).

antler morphology to a Neotropical deer species. Our results confirm the veracity of this technique for the differentiation of branch-antlered marsh deer males. Despite the fact that no males with velvet antlers were recorded in this survey, special attention must be given to those records if they appear, due to the ongoing growth of velvet antlers. Similarly, survey duration should not be neglected and short term sampling is the best choice because males can shed their antlers anytime of the year and young males tend do it more frequently (Pereira, 2010; H. G. C. Ramos, unpubl. data)

The density determined by the camera trap method was similar to that estimated by the traditional methodology of sampling by distances obtained during the aerial survey. Although these methods presented wide confidence intervals, they were similar and compatible with the range of density values reported for the species, which vary from 0.32 to 0.99 ind $/ \mathrm{km}^{2}$, though in some regions they can reach $1.8 \mathrm{ind} / \mathrm{km}^{2}$. (Mourão \& CAMPos, 1995; Pinder, 1996; MourÃo et al., 2000; Tomas et al., 2001; ANDriolo et al., 2005; Tiepolo et al., 2010). Due to the propensity of seasonal changes to influence distribution and movement patterns in the species (Tomas et al., 2001), it is necessary to highlight that densities
Tab. I. Marsh deer demographic parameters results and costs of camera trap and aerial surveys conducted at the Jataí Ecological Station, state of São Paulo. Brazil. Density (individual/kilometer ${ }^{2}$ ), number of individuals (n), males (M) and females (F).

\begin{tabular}{lcc}
\hline & Camera trap & Aerial Survey \\
\hline Density (ind $\left./ \mathrm{km}^{2}\right)$ & 0.98 & 1.06 \\
$(95 \% \mathrm{CI})$ & $(0.69-1.66)$ & $(0.58-1.90)$ \\
Adult/fawn (n) & $19 / 1$ & $42 / 0$ \\
Sex ratio (M/F) & $13 / 6$ & \\
Cost (US\$) & 650 & 3000 \\
Effort (h/person) & 300 & 15 \\
\hline
\end{tabular}

decribed here were observed at the end of the dry season, at which it is expected that the animals would occupy the whole area of the floodplain in a more distributed way (M. A. A. Perin, unpubl. data).

Increasing the sampling effort would contribute to a larger number of records and, consequently, increases the accuracy of the population estimate. Research on the whitetailed deer assessed trap density and verified that increasing the density resulted in better estimates (JACOBSON et al., 1997) and improved cost (CURTIs et al., 2009), reaching a 
concentration of one camera trap for every 33 ha. In this work, a sample effort of one camera trap for every 106 ha was used, respecting the minimum spacing that would guarantee the "capture" of the largest number of different deer. Unlike white-tailed deer, the marsh deer is a predominantly solitary species, with larger home ranges, and is not attracted by baits (PINDER, 1996; PioveZAN et al., 2010). Using greater trap density to increase the success of captures and reduce the sampling time could be an interesting way to increase the cost-benefit of the technique. Another alternative is to increase the number of cameras per sampling site to increase detectability (PEASE et al., 2016).

Other demographic parameters, such as sex ratio and age proportions are of equal importance in supporting the management of ungulate species (BENDER, 2006; POHLER et $a l ., 2014)$. However, aerial surveys of the marsh deer do not provide these data (MOURÃo \& CAMPOS, 1995; MourÃo et al., 2000; Tomas et al., 2001; TiEPOLO et al., 2010), and it has been reported that sexual identification is not possible in $74 \%$ of sightings (ANDRIOLO et al., 2005). Our aerial sampling allowed us to identify nine antlered males (not individualized), but verifying the sex ratio was not possible. In addition to the possibility of males without antlers, the speed of the helicopter and rapid sightings hinder correct identification. The use of camera traps is therefore important to obtain more detailed information about the animals observed. In our camera trap sampling, sex identification was evident, which allowed us to estimate the sex ratio of the population studied.

The difference in detectability between the sexes is a factor that could skew the sex ratio obtained using camera trap data and bias the overall density estimate as well (WECKEL et $a l ., 2011)$. This difference could be related to differences in movement, in home range sizes and in reproductive seasons (JACOBSON et al., 1997; WeCKel et al., 2011). Animals with higher movement rates tend to be more easily detectable, which could have biased the observed ratio (SolLmann $e t$ al., 2011). A deviation to a male-biased sex ratio, when the proportion is actually equal, could underestimate the overall density obtained with a camera trap survey (Moore et al., 2013). Despite the fact that white-tailed deer males can travel twice as far as females in a day (WEBB et al., 2010) no bias was observed in detectability by sex or recapture rates for males and females (ROBERTs et al., 2006; WATTS et al., 2008). McCoy et al. (2011), highlighting that the main reason for sexual bias corresponds to different responses to bait attraction. Studies that do not use bait have determined sex ratios using camera traps without further discussion (SHIELDS et al., 2012; IKEDA et al., 2013). WeCKel et al. (2011) approached this issue proposing a standardized rather than raw photographic ratio to correctly adress the sex ratio. Considering this, future studies with more robust numbers of independent records should consider this approach.

Though marsh deer males have home ranges that are almost double the size of females', it is not known if males move with greater intensity (PiovezAn et al., 2010). The sex ratio observed in this work indicates that males are twice as common as females in the population, which is not an expected situation in deer with a polygynus maiting system. PINDER (1996) estimated the proportion of females of a marsh deer population on the Paraná River, finding a 2:1 female/male proportion, but indicated a bias due to incorrect identification of young males without antlers. A real malebiased proportion could be related to environmental stress (low resource availability), inducing a biased sex ratio on birth (Hewison \& GaILlaRD, 1996). This is not a negligible hypothesis in the view of the number of individuals living in such a small area. Nevertheless, the importance of obtaining fine scale movement patterns of marsh deer is clear in this context in order to better understand detectability differences among individual classes.

Similarly to sex ratios information, determining age proportions or detecting the frequency of fawns in a population are essential to understanding population recruitment and to infer about population dynamics (Bender, 2006; PoHLER et al., 2014). In this regard, once again the camera traps were more informative. They allowed for observation of a very young fawn accompanying and feeding on its mother, and the identification of a male with a simple spiked antler. Both these cases are practically infeasible by aerial survey, and only ANDriolo et al. (2005) and PINDER (1996) have reported the occasional sighting of a fawn and mother.

For a population survey technique to be useful, having good accuracy is not enough, its costs must be consistent with the reality where it will be applied. Aerial surveying is a technique that is consecrated precisely because of its cost benefit when covering large areas (CAUGHLEY \& GRIGG, 1981). However, its use in small areas may be infeasible (KoERTH et al., 1997). Changing methodologies from aerial survey to the use of camera traps in the management of whitetailed deer populations in the United States represented a more feasible approach for smaller, suburban populations or those living in denser habitats (RoBERTs et al., 2006; CURTIS et al., 2009). The current perspective of habitat loss and fragmentation of many species, such as the marsh deer, into small relictual populations represents a condition where the use of aerial surveys may be impractical. Our study clarifies that to obtain similar results, the use of camera traps cost $21.7 \%$ of the aerial survey.

We opted to adjust the equipment costs to their useful life, as proposed by KörTH et al. (1997), on the understanding that this better represents the operational costs of the sampling method. This makes sense in a context where the use of camera traps has become widespread and diffuse (Rowcliffe \& CARBOne, 2008). Our relative cost expressed in relation to the studied area was US\$ $0.43 / \mathrm{ha}$, which would be US\$ 4.08 /ha in the absence of any adjustment to the useful life of the equipment. This is similar to that reported by a recent study in the USA, which also used digital cameras and estimated an expenditure of US\$ 5.56/ha without considering the period they were used for (DOUGHERTY \& Bowman, 2012).

In contrast to the much lower cost presented by the camera trap survey compared to the aerial survey; this method 
presented a far greater field effort that should be taken into account. Our work indicated that the difference could be 20 times greater than in an aerial count, in field effort alone. This did not include the effort expended in subsequent analysis of the data obtained, which could be important in studies applying intensive camera trap monitoring (DOUGHERTY \& Bowman, 2012). Those aspects demonstrated that, in some cases, the lower financial costs of camera trap surveys do not compensate for the greater expenditure of effort required to perform studies using this technique.

On the other hand, the logistics of using a small aircraft is also an aspect that should be accounted for. The lack of availability of aircraft close to the area to be sampled is a known difficulty (CAUGHLEY \& GRIGG, 1981) and could be a major problem in the Neotropical region, where large urban centers are generally far from natural areas. Although not costed in this work, the movement of the aircraft from its base to the study area can considerably increase the working costs, or make it infeasible. This cost will depend directly on the sampling protocol (number of repetitions and days of flight) or the availability of the aircraft to remain at the study area throughout the sampling season. The choice of aircraft is also an important factor since a helicopter can cost five times more than a small airplane. However, given their navigability (speed and maneuverability), a helicopter becomes essential when working with populations restricted in small areas. Again, particular factors such as area format and vegetation composition (all open grasslands or forest/ open mosaic) are important in the decision.

In view of the presented aspects, not only the size of the study area but multiple factors are related to the price and the decision of which methodology to choose. Size and shape of the area, vegetation composition and visibility, accessibility in the field, distance from an airbase and availability of the aircraft should be taken into account. Similarly, DEYoung (2011) argues that the existence of multiple factors makes evaluation dependent on the local context in the decision process regarding the population management of deers in the USA without a general recommendation that fulfills all possibilities.

Considering the scarcity of resources for studying and monitoring wildlife in developing countries, expensive forms of monitoring could be prohibitive. This is evident when considering that only seven studies have involved aerial surveys in 40 years of work on the marsh deer (SCHALLER \& VASCONCELOS, 1978; MourÃo \& CAMPos, 1995; Pinder, 1996; Mourão et al., 2000; TOMAS et al., 2001; ANDRIOLO et al., 2005; TiEPOLO et al., 2010). Our study shows the possibilities of applying camera traps to identify branchantlered males and determine demographic parameters, such as density, sex ratio and the frequency of young males and fawns. Despite requiring a much greater field effort, this methodology has a much higher cost-benefit compared to aerial surveys, because it is more informative, cheaper and the logistics are simpler. Irrespective of the need to more clearly understand the difference in detectability between population groups and to optimize sampling through trap density, the repeated application of single sampling surveys like ours extends the possibilities for studying larger numbers of populations or even a single population in a continuous monitoring framework. Such long-term approaches are essential to understanding the demographic patterns and trends yet to be defined for the endangered marsh deer.

Acknowledgments. Field work for this study was supported by Funbio in the context of Tropical Forest Conservation Act grant and the authors PHFP and MLO receives a scholarship from FAPESP. We thank FUNEP and NUPECCE for logistical support, the Instituto Florestal de São Paulo (COTEC SMA: 260108-004.556/2013) and the Instituto Chico Mendes de Conservação da Biodiversidade (SISBIO 38267-2) for permission to conduct research in the study site. Finally we sincerely thank Jonathan Hill for English review of the manuscript.

\section{REFERENCES}

Akaike, H. 1985. Prediction and entropy. In: Atkinson, A. C. \& FienberG, S.E. eds. A Celebration of Statistics. Berlin, Springer-Verlag, p. 1-24. Andriolo, A.; Piovezan, U.; Costa, M. J. R. P.; LaAke, J. \& Duarte, J. M. B. 2005. Aerial line transect survey to estimate abundance of marsh deer (Blastocerus dichotomus) (Illiger, 1815). Brazilian Archives of Biology and Technology 48:807-814.

Andriolo, A.; Piovezan, U.; Costa, M. J. R.; Torres, H. A.; Vogliotti, A.; Zerbini, A. N. \& DuARTE, J. M. B. 2013. Severe population decline of marsh deer, Blastocerus dichotomus (Cetartiodactyla: Cervidae), a threatened species, caused by flooding related to a hydroelectric power plant. Zoologia 30:630-638.

BENDER, L. C. 2006. Uses of herd composition and age ratios in ungulate management. Wildlife Society Bulletin 34:1225-1230.

Cabrera, A. 1961. Catálogo de los mamíferos de América del Sur. Revista del Museo Argentino de Ciencias Naturales "Bernardino Rivadavia" 4:309-732.

Carbone, C.; Christie, S.; Conforti, K.; Coulson, T.; Franklin, N.; GinsberG, J. R.; Griffiths, M.; Holden, J.; KaWAnishi, K.; Kinnaird, M.; Laidlaw, R.; Lynam, A.; Macdounal, D.W.; Martyr, D.; McDougal, C.; Nath, L.; O’Brien, T.; Seidensticker, J.; Smith, D. J. L.; Sunquist, M.; Tilson, R. \& Wan Shahruddin, W. N. 2001. The use of photographic rates to estimate densities of tigers and other cryptic mammals. Animal Conservation 4:75-79.

Caughley, G. 1977. Sampling in aerial survey. Journal of Wildlife Management 41:605-615

Caughley, G. \& Grigg, G. C. 1981. Surveys of the distribution and density of kangaroos in the pastoral zone of south Australia, and their bearing on the feasibility of aerial survey in large remote areas. Australian Wildlife Research 8:1-11

Curtis, P. D.; Boldgiv, B.; Mattison, P. M. \& Boulanger, J. R. 2009. Estimating deer abundance in suburban areas with infrared-triggered cameras. Human-Wildlife Interaction 3:116-128.

DeYoung, C. A. 2011. Population dynamics. In: Hewitt, D. G. ed. Biology and management of white-tailed deer. Boca Raton, CRC Press, p. 147-180.

Dougherty, S. Q. \& Bowman, J. L. 2012. Estimating sika deer abundance using camera surveys. Population Ecology 54:357-365

DuARTE, J. M. B. 1996. Guia de identificação de cervídeos brasileiros. Jaboticabal, FUNEP.16p.

Duarte, J. M. B.; Piovezan, U.; Zanetti, E. S.; Ramos, H. G. C.; Tiepolo, L. M.; Vogliotti, A.; Oliveira, M. L.; Rodrigues, L. F. \& Almeida, L. B. 2012. Avaliação do risco de extinção do cervo-do-pantanal Blastocerus dichotomus Illiger, 1815, no Brasil. Biodiversidade Brasileira 2:3-14.

Duarte, J. M. B.; Varela, D.; Piovezan, U.; Beccaceci, M. D. \& Garcia, J. E. 2016. Blastocerus dichotomus. The IUCN Red List of Threatened Species 2016: e.T2828A22160916. Available at $<$ http:// www.iucnredlist.org/details/2828/0>. Accessed on 24 November 2016. 
Figueira, C. J. M.; Pires, J. S. R.; Andriolo, A.; Costa, M. J. R. P. \& DuARTe, J. M. B. 2005. Marsh deer (Blastocerus dichotomus) reintroduction in the jatai ecological station (Luis Antonio, SP): Spatial preferences. Brazilian Journal of Biology 65:263-270.

Foster, R. J. \& HARMSEN, B. J. 2012. A critique of density estimation from camera-trap data. The Journal of Wildlife Management 76:224-236.

Hewison, A. M. \& Gaillard, J. M. 1996. Birth-sex ratios and local resource competition in roe deer, Capreolus capreolus. Behavioral Ecology 7(4):461-464.

Hofmann, R. K.; Prado, C. F. P. \& Otte, K. C. 1976. Registro de dos nuevas especies de mamíferos para el Perú, Odocoileus dichotomus (Illiger - 1811) y Chrysocyon brachyurus (Illiger - 1811), con cotas sobre su habitat. Revista Forestal del Perú 6:1-25.

Ikeda, T.; Takahashi, H.; Yoshida, T.; Igota, H. \& Kaji, K. 2013. Evaluation of camera trap surveys for estimation of sika deer herd composition. Mammal Study 38:29-33.

Jacobson, H. A.; Kroll, J. C.; Browning, R.W.; Koerth, B. H. \& Conway, M. H. 1997. Infrared-triggered cameras for censuring white-tailed deer. Wildlife Society Bulletin 25:547-556.

JunQueIRA, J. F. D. 1940. Veados do Brasil: O cervo. Chácaras e Quintais 62:330-331.

KarANTH, K. U. \& NiCHOLS, J. D. 1998. Estimation of tiger densities in India using photographic captures and recaptures. Ecology 79:2852-2862.

Karanth, K. U.; Nichols, J. D. \& Kumar, N. S. 2004. Photographic sampling of elusive mammals in tropical forests. In: Thompson, W. L. ed. Sampling Rare or Elusive Species. Washington, Island Press, p.229-247.

Kelly, M. J.; Noss, A. J.; Di Bitetti, M. S.; Maffei, L.; Arispe, R.; Paviolo, A.; De Angelo, C. D. \& Di Blanco, Y. E. 2008. Estimating puma densities from camera trapping across three study sites: Bolivia, Argentina, Belize. Journal of Mammalogy 89:408-418.

Kenney, A. J. \& Krebs, C. J. 1998. Programs for Ecological Methodology. Version 5.2. Available at: <http://www.zoology.ubc.ca $>$.

Koerth, B. H.; Mckown, C. D. \& Kroll, J. C. 1997. Infrared-triggered camera vesus helicopter counts of white-tailed deer. Wildlife Society Bulletin 25: 557-562.

LaAke, J. L.; Buckland, S. T.; Anderson, D. R. \& Burnham, K. P. 1993. Distance user's guide. Fort Collins, Colorado Cooperative Fish and Wildlife Research Unit, Colorado State University. 72p.

McCoy, J. C.; Ditchkoff, S. S. \& Steury, T. D. 2011. Bias associated with baited camera sites for assessing population characteristics of deer. Journal of Wildlife Management 75:472-477.

Moore, M. T.; Foley, A. M.; DeYoung, C. A.; Hewitt, D. G.; Fulbright, T. E. \& Draeger, D. A. 2013. Evaluation of population estimates of white-tailed deer from camera survey. Journal of the Southeastern Association of Fish and Wildlife Agencies 1:127-132.

Mourão, G. \& CAmpos, Z. 1995. Survey of broad-snouted caiman Caiman latirostris, marsh deer Blastocerus dichotomus and capybara Hydrochaeris hydrochaeris in the area to be inundated by Porto Primavera Dam, Brazil. Biological Conservation 73:27-31.

Mourão, G.; Coutinho, M.; Mauro, R.; Campos, Z.; Tomás, W. \& Magnusson, W. 2000. Aerial surveys of caiman, marsh deer and pampas deer in the Pantanal Wetland of Brazil. Biological Conservation 92:175-183.

Noss, A. J.; Cú́llar, R. L.; Barrientos, J.; Maffei, L.; Cuéllar, E.; Arispe, R.; Rumiz, D. I. \& Rivero, K. 2003. A camera trapping and radio telemetry study of Tapirus terrestris in Bolivian dry forests. Tapir Conservation 12:24-32.

Pease, B. S.; Nielsen, C. K. \& Holzmueller, E. J. 2016. Single-camera trap survey designs miss detections: impacts on estimates of occupancy and community metrics. PloS One 11(11): e0166689.

Pereira, R. J. G. 2010. Male Reproduction. In: Duarte, J. M. B. \& GonzÁlez, S. eds. Neotropical Cervidology: Biology and Medicine of Latin American Deer. Jaboticabal, Funep/IUCN. 394p.

PINDER, L. 1996. Marsh deer Blastocerus dichotomus population estimate in the Paraná River, Brazil. Biological Conservation 75:87-91.

Pinder, L. \& Grosse, A. P. 1991. Blastocerus dichotomus. Mammalian Species Archive 380:1-4.

Piovezan, U.; Tiepolo, L. M.; Tomas, W. M.; Duarte, J. M. B.; Varela, D. \& Marinho-Filho, J. S. 2010. Marsh Deer Blastocerus dichotomus
(Illiger, 1815), p. 66-76. In: Duarte, J.M.B. \& GonzÁlez, S. eds. Neotropical Cervidology: Biology and Medicine of Latin American Deer. Jaboticabal, Funep/IUCN. 394p.

Pohler, P. S.; Harveson, L. A. \& Harveson, P. M. 2014. Demographic characteristics of elk in the Glass Mountains, Texas. Wildlife Society Bulletin 38:466-472.

Ridout, M. S. \& Linkie, M. 2009. Estimating overlap of daily activity patterns from camera trap data. Journal of Agricultural, Biological, and Environmental Statistics 14:322-337.

Roberts, C. W.; Pierce, B. L.; Braden, A. W.; Lopez, R. R.; Silvy, N. J.; Frank, P. A. \& Ransom, D. 2006. Comparison of camera and road survey estimates for white-tailed deer. Journal of Wildlife Management 70:263-267.

Rovero, F. \& Marshall, A. R. 2009. Camera trapping photographic rate as an index of density in forest ungulates. Journal of Applied Ecology 46:1011-1017.

Rowcliffe, J. M. \& CARbone, C. 2008. Surveys using camera traps: Are we looking to a brighter future? Animal Conservation 11:185-186.

São Paulo. 2013. Plano de Manejo da Estação Ecológica de Jataí. São Paulo, Secretaria do Meio Ambiente, Fundação Florestal. 302p.

Schaller, G. B. \& Vasconcelos, J. M. C. 1978. A Marsh Deer Census in Brazil. Oryx 14:345-351.

Schumacher, F. X. \& Eschmeyer, R. W. 1943. The estimation of fish population in lakes and ponds. Journal of the Tennessee Academic Science 18:228-249.

Shields, A. V.; Larsen, R. T. \& Whiting, J. C. 2012. Summer watering patterns of mule deer in the Great Basin Desert, USA: implications of differential use by individuals and the sexes for management of water resources. The Scientific World Journal 2012:1-9.

Sollmann, R.; Furtado, M. M.; Gardner, B.; Hofer, H.; JÁcomo, A. T.; Tôrres, N. M. \& SilveIRA, L. 2011. Improving density estimates for elusive carnivores: accounting for sex-specific detection and movements using spatial capture-recapture models for jaguars in central Brazil. Biological Conservation 144(3):1017-1024.

Thomas, L.; Buckland, S. T.; ReXstad, E. A.; LAake, J. L.; StrindberG, S.; Hedley, S. L.; Bishop, J. R. B.; Marques, T. A. \& Burnham, K. P. 2010. Distance software: Design and analysis of distance sampling surveys for estimating population size. Journal of Applied Ecology 47:5-14.

Tiepolo, L. M.; Tomas, W. M. \& Lima-Borges, P. A. 2010. Levantamento populacional do cervo-do-pantanal Blastocerus dichotomus (Mammalia, Cervidae) no Parque Nacional de Ilha Grande e entorno: implicações para a conservação. Iheringia, Série Zoologia 100:111-115.

Tomas, W. M.; Beccaceci, M. D. \& Pinder, L. 1997. Cervo-do-Pantanal. In: Duarte, J. M. B. ed. Biologia e Conservação de cervídeos sulamericanos: Blastocerus, Ozotocerus e Mazama. Jaboticabal, FUNEP, p. 24-40.

Tomas, W. M.; Salis, S. M.; Silva, M. P.; Mourão, G. M. 2001. Marsh deer (Blastocerus dichotomus) distribution as a function of floods in the pantanal wetland, Brazil. Studies on Neotropical Fauna and Environment 36:9-13

Trolle, M.; Noss, A. J.; Cordeiro, J. L. P. \& Oliveira, L. F. B. 2008. Brazilian tapir density in the Pantanal: A comparison of systematic camera trapping and line transect surveys. Biotropica 40:211-217.

Trolle, M.; Noss, A. J.; Lima, E. S. \& Dalponte, J. C. 2006. Cameratrap studies of maned wolf density in the Cerrado and the Pantanal of Brazil. Biodiversity and Conservation 10:1197-1204.

Watts, D. E.; PARker, I. D.; Lopez, R. R.; Silvy, N. J. \& Davis, D. S. 2008. Distribution and abundance of endangered Florida Key deer on outer islands. Journal of Wildlife Management 72(2):360-366.

Webb, S. L.; Gee, K. L.; Strickland, B. K.; Demarais, S. \& DeYoung, R. W. 2010. Measuring fine-scale white-tailed deer movements and environmental influences using GPS collars. International Journal of Ecology 2010: 459610. doi: 10.1155/2010/459610

Weckel, M.; Rockwell, R. F. \& Secret, F. 2011. A modification of Jacobson et al.'s (1997) individual branch-antlered male method for censusing white-tailed deer. Wildlife Society Bulletin 35:445-451.

WiLson, K. R. \& ANDERSON, D. R. 1985. Evaluation of two density estimators of small mammal population size. Journal of Mammalogy 66:13-21. 